\title{
Ibn Sīnā and conflict in logic
}

\author{
Wilfrid Hodges \\ Herons Brook, Sticklepath, \\ Okehampton, Devon EX20 2PY, England \\ wilfrid.hodges@btinternet.com
}

\section{Introduction}

This draft suppresses some not-yet-public information about Festschrifts.

I thank Amirouche Moktefi and Dimitri Gutas for helpful comments; in particular Amirouche read through the Arabic with me and made many improvements to the translation. Of course any mistakes are my responsibility.

\section{De Interpretatione chapter 14}

\subsection{The text translated below}

During the 1020s Ibn Sīnā wrote a commentary in Arabic on the logical works of Aristotle, as part of his encyclopedia Al-Šifä' (The Cure). The commentary runs to some 2180 pages in the recent Cairo edition; this figure includes his commentary Madkal on Porphyry's Eisagōgē, which he counted as an introduction to Aristotle's work. Apart from the Madkal which was translated into Latin in the 12th century, and the section of Qiyass dealing with propositional logic, barely any of Ibn Sīnā's commentary has been translated into any western language.

Ibn Sīnā refers to Aristotle's texts as 'The First Teaching' (as in [2.5.7], [2.5.9] below). Their first five books are the subjects of the second to sixth volumes of the Šifä́ respectively. After Madkal which comments on the Eisagōgē, there come Maqūlāt (on Aristotle's Categories), ' Ibāra (on Perì Hermēneías), Qiyās (on Prior Analytics), Burhān (on Posterior Analytics) and Jadal (on Topics). Ibn Sīnā also commented on the Sophistical Refutations, Rhetoric and Poetics, but we won't use these commentaries. We will cite two later works of Ibn Sīnā: the Easterners and the 'Išărāt. 
The passage translated in $\S 6$ below is section 2.5 from Ibn Sīnā's commentary ${ }^{c} I b \bar{a} r a$ on Aristotle's Perì Hermēneías, the book that the Latins knew as De Interpretatione. Ibn Sīnā is commenting on section 14 of the Perì Hermeneias; henceforth I abbreviate this to PH14. The commentator Stephanus who probably taught in Alexandria around AD 600 - said of this passage

The enquiry now undertaken is certainly not Aristotle's, but is written as an exercise. That is why Porphyry, writing a lengthy commentary on [Perì Hermèneías], did not judge this section worthy of the thought needed to clarify it. ([6] p. 185. Ammonius [3] says similar things in more detail.)

In fact most commentators have found it difficult to fit the passage convincingly into Perì Hermèneías, or even to make sense of it on its own. This is helpful for us in two ways. First, the passage is a misfit, so we can reasonably take it separately from the rest of Perì Hermenneías. Second, it will serve to illustrate how Ibn Sīnā deals with challenging material.

My title - 'conflict in logic' - has two meanings. First we will see that Ibn Sīnā takes up the view of some earlier commentators, that Aristotle's passage is about conflict as a notion related to logic. Second, Ibn Sīnā was notorious for treating other logicians with disdain, and one of his livelier paragraphs here is a vivid demonstration of how to wipe the floor with people you despise. I think Ibn Sīnā is not just being obnoxious; he has a significant point to make about how to do logic.

\subsection{Ways of teaching}

The aristotelian commentators set themselves the task of making Aristotle consistent with himself. They developed a battery of excuses for the contradictions and obscurities that they found in him. It became a cardinal point that Aristotle intentionally made himself difficult to understand. Thus Ibn Sīnā's predecessor Al-Fārābī:

... the person who researches the Aristotelian sciences, studies his books, and applies himself with perseverance to them, knows full well the different methods he used to render things inacces-

(2) sible, cryptic, and intricate, despite his express intent to expound and explain. Among these [methods] are the following:

i. In many of the syllogisms ... he omits the necessary premiss. (Etc. through five methods.) 
Dimitri Gutas argues that Ibn Sīnā accepted what he took to be Aristotle's reasons for this policy, and sometimes copied Aristotle by adopting a similar obscurity. Thus Ibn Sīnā writes:

Whatever I am able to bring to light I will do so either openly, or from behind a veil which acts as a useful kind of stimulus and drill ...

(Gutas [8], p. 228 for the Al-Fārābī quotation and p. 307 for the Ibn Sīnā.)

In fact Ibn Sīnā does assume that the obscurities of PH14 are deliberate, but he has another explanation for them. In Qiyās he makes the following remarks:

Teaching is of two kinds. [First there is] teaching which supplies knowledge of something that wasn't already known in the nature of things; as when one teaches that the three angles of a triangle are equivalent to two right angles. [Second there is] teaching that consists of reminding (tadkirr) and facilitating (' $\left.i^{c} d \bar{a} d\right)$. Reminding is what causes a thing to come into the mental processor $(b \bar{a} l)$ when the thing was already known. ... Facilitation is that a thing comes into the mental processor together with other things that have similar properties to it. Each of these other things, when it is known, gives no further knowledge beyond itself; but when [the first thing] is brought into the mental processor in the vicinity of this thing, the two of them [together] supply new knowledge.... Perì Hermèneías mostly consists of reminding and facilitating, though some of it is argument and reasoning. (Qiyās 15.13-17.1. On 'mental processor' see $\S 3.2$ below and the notes on [2.5.13].)

In paragraphs [2.5.9] and [2.5.10] of his commentary on PH14, Ibn Sīnā states his view that this section of Perì Hermēneías, or at least a major part of it, was written as a facilitation. (He says tawti $i^{\prime} a$; this is a near synonym of ' $i c d \bar{a} d$, and there is no reason to think that he means anything different by it.)

The notion of facilitation as a style of teaching seems to be Ibn Sīnā's own. I think it entitles him to a mention in the history of cognitive science. There is more to be said on this, but not here.

The thing to take home here is that on Ibn Sīnā's account, Aristotle is making points not for their own sake, but so that they can serve as catalysts for the student to develop other related pieces of insight. So there is no need for PH14 to hang together. Its overall structure is not what the student 
should be learning from it. Rather it gives the student a collection of bullet points that can facilitate other knowledge in analogous situations.

Ibn Sīnā writes his commentary on PH14 in a similar style. He makes points that should be followed up but aren't. He jumps forwards and backwards through Aristotle's text for no apparent reason. With the exception of the remarkable paragraph [2.5.16], he gives many suggestions but few arguments. He is surprisingly casual about whether his explanations are accurate to Aristotle's intentions. In the context described above, one can see why he could have thought that this was an appropriate way to treat a historical text; today we would regard it as less than professional.

\subsection{Summary of Aristotle's text}

Ibn Sinnā will have had available to him the excellent Arabic translation of Aristotle's text made around the year 900 by 'Ishāq ibn Hunain. This translation survives, but Ibn Sīnā tends to quote so loosely that it's hard to be sure exactly what he is quoting. (For an example see the note on 131.12 'Contraries' below.)

The following summary of Aristotle's argument imposes a shape that may go some way beyond what Aristotle himself intended. Incoherent arguments are very hard to summarise without imposing some kind of coherence. Ackrill [1] translates the passage with a commentary.

At $17 \mathrm{~b} 4$ earlier in the Perì Hermēneías, Aristotle has explained that the two sentences 'Every $\mathrm{A}$ is an $\mathrm{X}^{\prime}$ and 'No $\mathrm{A}$ is an $\mathrm{X}^{\prime}$ are contraries (enantíai) of each other. This was by stipulation; in the present passage, Aristotle aims to give a heuristic argument to justify the stipulation on the basis of more fundamental principles.

The principles that he assumes are as follows:

1. For every proposition $p$ there is a proposition $q$ such that $p$ and $q$ are contraries of each other. (Implicit in 23a27-30.)

2. If $p, q, r$ are propositions and both $q$ and $r$ are contraries of $p$, then $q$ and $r$ express the same belief. (Implicit in 23a32-35.)

3. If $p$ is a contrary of $q$ then $p$ and $q$ can't both be true. (24b9.)

Step 1 (23a32-39). Aristotle begins by reducing the question to one about beliefs. I guess that this is in order to replace the equivalence relation in Principle 2 by identity. But in fact he continues his argument in terms of the propositions expressing the beliefs. 
Step 2 (23a40-23b7). Next he considers the case of singular propositions. An affirmative singular proposition has the form

(5) $A$ is an $X$.

and a negative singular proposition has the form

(6) $B$ is not an $X$.

Aristotle claims that if the subjects $A$ and $B$ are distinct, then in general nothing prevents (5) and (6) from both being true, even with the same $X$; and the same holds between two affirmatives or two negatives. So we conclude that two singular propositions that are contrary to each other must have the same subject.

Step 3 (implicit in 23b7-9). Next he points out that if (5) is contrary to a singular proposition $q$, then $q$ must entail

(7) $\quad A$ is not an $X$.

Otherwise Principle 3 is violated.

Steps $4 a, 4 b, 4 c$. Having established this, he gives three arguments why the contrary of (5) must be (7) (up to identity of belief). The first argument (Step 4a, 23b7-27) is very obscure; maybe Aristotle intended it to be more than one argument. It includes two further notions: that of a thing being true essentially as opposed to accidentally, and that of a belief being further from the truth than another belief.

The second argument (Step 4b, 23b27-32) is that for some particular values of $A$ and $X$ the only candidate for a contrary of (5) is (7). But the generality in Principle 1 implies that there is some uniform formula for reaching the contrary. The third argument (Step 4c, 23b33-24a3) is broadly similar, but in the opposite direction: the contrary of (7) can only be (5), and so the contrary of (5) is (7) by the symmetry in Principle 1.

Step 5 (24b1-6). Finally Aristotle reaches his conclusion as follows. By analogy with singular propositions, the contrary of

(8) Every $A$ is an $X$.

must have the same subject as (8). Now the subject of (8) is $A$, taken universally; so the same must hold for its contrary. Also by analogy with singular propositions, the contrary of (8) should conclude '... is not $X^{\prime}$. Putting these together, the contrary of (8) is

(9) Every $A$ is not an $X$.

As required, this expresses the same belief as 'No $A$ is an $X^{\prime}$. 


\section{Ibn Sīnā's semantics}

\subsection{Ideas}

For Ibn Sīnā, logic is about ideas (he calls them 'things', 'ašya'). More precisely it's about how ideas are derived from other ideas by definition or deduction. Ideas are objective entities, as distinct from the representations of ideas in your mind or my mind. In fact Ibn Sīnā believes that there is a divine intellect that holds the stock of ideas. But he has a strong antipathy to mixing logic and metaphysics, so he never mentions this point in his logical writings.

A typical idea is the meaning of a word or meaningful phrase of a natural language. Here we need some notation. I use quotes to name words and phrases:

(10) 'not a horse'

and semantic quotes (in the style of Jackendoff [20] and others) to name the meanings of words and phrases:

\section{(11) [NOT A HORSE]}

Ibn Sīnā himself has neither of these notations. For the first he would write the equivalent of

(12) the phrase not a horse.

He has no expression for semantic quotes, but there are a number of phrases that serve as a cue that he is talking about meanings. For example in [2.5.5] below he says the Arabic equivalent of 'as for it isn't good itself'; he is talking about the meaning [NOT GOOD]. (See the note on 125.17 below.) A more extravagant example is

(13) not-a-horse-ness insofar as it is not-a-horse-ness

(Maqūlāt [12] 242.3), which refers to [NOT A HORSE].

A typical idea like [HORSE] has at its core a principle for classifying actual or possible entities into two sorts, those which satisfy it and those which don't. This principle is (near enough for present purposes) what Ibn Sīnā calls the 'nature' $\left(t a b \bar{\imath}^{c} a\right)$ of the idea.

Some ideas are atomic and come to us direct. Others are compound; their nature is built up from the natures of simpler ideas. A typical compound idea like [HORSE] has a feature which records how the nature is 
built up. This feature is called the 'essence' (d्āt) or 'whatness' (māhiyya) of the idea. The idea also has a 'definition', which is a linguistic expression that reports the essence in a canonical form. The simpler ideas from which an idea is formed are said to be 'internal' (dākil) to the idea or the definition. For example [ANIMAL] is internal to [HORSE], and [NECESSARY] is internal to [POSSIBLE].

The essence of [HORSE] actually contains [ANIMAL] as a conjunct: to check that a thing is a horse, you need to check among other things that it's an animal. We can express this by saying that [ANIMAL] is 'constitutive' (muqawwim) for [HORSE], or that it's a constitutive of [HORSE]. Unfortunately we often meet loose vocabulary in this area. For example when Ibn Sīnā says that $I$ is 'essential' for $J$, he sometimes seems to mean that it's internal, and sometimes that it's constitutive. Constitutive implies internal but not vice versa; for example [NECESSARY] is certainly not constitutive for [POSSIBLE].

This confusion arises from an endemic false assumption of aristotelian logic, which I discuss in [9] under the name of Top-Level Processing. Briefly, the assumption is that logical processing never reaches below the top syntactic level. Ibn Sīnā deserves credit for making the assumption explicit, but (at least in the West) we have to wait till Frege to see a serious assault on it.

The way it shows up in connection with 'internal' is that definitions are required to express intersections; for example

So the definition has to be composed from the genus and the dif(14) ferentia ... as when we define 'human' by saying 'Human is animal that is rational' (Madkal [11] 48.17-19).

... composition in the form of restriction, which is what happens when we obtain concepts through definitions ... ( ${ }^{c} I b \bar{a} r a[13]$ 31.16f).

(In all ages of aristotelian logic, $a \cap b$ is thought of as $b$ restricted to $a$. As Boole puts it, 'The mental operation represented by the adjective ... is that of selecting from a certain class as subject all the individuals which together answer to a given description. ... the subject class is expressed by that word or combination of words to which the adjective is prefixed.' [5] p. 5.) Thanks to Top-Level Processing, the theory of definitions tends to fasten on the top-level constitutives and overlook features that are lower down in the syntactic structure, such as negations on subphrases. 


\subsection{Attachments}

We can form the idea [HUMAN]. We can also form the ideas [RATIONAL HUMAN] and [YOUNG HUMAN]; let us express this by saying that the ideas [RATIONAL] and [YOUNG] are 'attachments' of the idea [HUMAN]. There is a crucial difference between these two attachments: [RATIONAL] is (for aristotelians) constitutive for [HUMAN], but [YOUNG] certainly isn't. Those attachments that are not constitutive are said to be 'accidents' ( ${ }^{c}$ arad). The distinction between constitutives and accidents is one of the fundamental principles of aristotelian philosophy, though not always in this terminology.

Aristotle himself said a number of things relevant to the distinction between constitutives and accidents, and the early commentators added more. By the late fourth century AD, the Phoenician philosopher Porphyry decided that the range of views on this and related topics had become a barrier to beginners in the field, and so he wrote his Eisagogge to draw some lines in the sand.

Porphyry divides attachments into three groups, namely non-accidents (i.e. constitutives), inseparable accidents ( ${ }^{c}$ arad gair mufäriq in the Arabic translation) and separable accidents ( ${ }^{c}$ arad mufāriq). (Eisagōge 12.25ff, [4] p. 12.) He classifies them by a device called 'removal', raf' in Arabic. Given an idea $I$ and an attachment $J$, we first form the idea NOT- $J$. (At this point an aristotelian would want to distinguish between removing $J$ and affirming NOT- $J$. For simplicity I suppress this distinction.) Are there any things that satisfy $I$ and NOT- $J$ ? If there aren't, then $J$ is a constitutive of $I$. If there are in the real world, then $J$ is a separable accident of $I$. If there aren't any in the real world, but we can imagine one, then $J$ is an inseparable accident of $I$. Thus [RATIONAL] is constitutive for [HUMAN] and [YOUNG] is a separable accident of [HUMAN]. Porphyry offers [BLACK] as an inseparable accident of [CROW].

Ibn Sīnā reviews this classification in his Madkal [11]. In places he merely reports what Porphyry said. Elsewhere ([11] 86.4ff) he gives a textbookish critique of the classification, scolding Porphyry for his careless formulations. But the full extent of Ibn Sīnā's disagreement with Porphyry comes to light when he forgets Porphyry and sets out his own views, in Madkal and elsewhere.

Like Porphyry, Ibn Sīnā divides attachments into three groups, but the groups are not Porphyry's. Ibn Sīnā distinguishes (1) the constitutives, (2) the inherents (läzim) and (3) the rest. The raf ${ }^{c}$ test plays no part in defining these groups. The constitutives of an idea $I$ are those ideas which are 
conjuncts of the essence of $I$, as we saw above. The inherents are those attachments that are not constitutive but follow necessarily from the essence of $I$.

Sometimes [an idea] has inherents that follow from it because of its whatness, though the whatness is established first and then these things follow from it. Thus [EVEN] follows from [TWO] .... (Madkal [11] 34.10f.)

A demonstration gives an inherent ... whereas a definition gives something in the constitutive essence. An inherent [of an idea] is not internal to the definition of the idea.... For example there is a demonstration telling us that a triangle has angles equal to two right angles; this meaning is external to the definition of [TRIANGLE]. (Burhān [15] 199.15-18.)

The third class consists of those attachments that don't follow from the essence of $I$.

How does this correlate with raf ${ }^{c}$ ? Strictly there are two forms of raf ${ }^{c}$, namely removal in the real world and removal in the imagination. Ibn Sīnā mentions the first, but he has very little interest in it. Logicians don't concern themselves with the actual world. As for removal in the imagination, he is clear that this can't happen with constitutives:

It's impossible to introduce into the mental processor both an idea and one of its constitutives, so that the idea is actually (18) present and the constitutive is negated from it; this would destroy the conceptualisation of the whatness. (Madkhal [11] 34.2135.3.)

But which accidents can be removed in the imagination? Ibn Sīnā's answer has two ingredients, one logical and one cognitive.

The logical part is that a proof of $J$ from $I$ can be long or short, depending on what $I$ and $J$ are. For Ibn Sīna the crucial dividing line is whether $I$ entails $J$ immediately, or whether you need to introduce an intermediate (mutawassit) idea in order to deduce $J$ from $I$. For example, part of the statement of Proposition I.32 of Euclid's Elements is that the internal angles of a (plane) triangle $A B C$ add up to the sum of two right angles. Euclid proves this by first extending the side $B C$ to $B D$, then adding a line seg- 
ment $C E$ parallel to $B A$ :

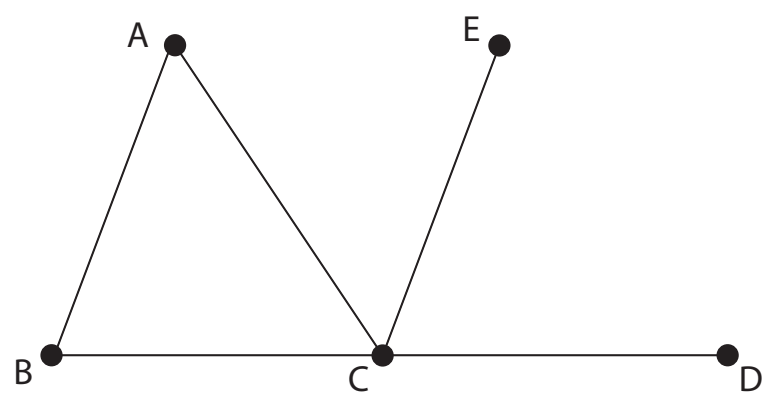

Then by earlier propositions in the Elements, the angles $A C E$ and $E C D$ are respectively equal to $B A C$ and $A B C$, and the theorem follows at once. The theorem shows that [ANGLES $180^{\circ}$ ] is an inherent of [TRIANGLE]. But at least by this proof, it's not an immediate inherent. Ibn Sīnā thinks that the possibility of extending the side $B C$ to $B D$ is an immediate inherent of [TRIANGLE], but the segment $C E$ adds a whole new idea (Madkal [11] 35.20-36.3).

This theorem has a history. Proclus in the fifth century AD ([24] 296ff) mentions two other proofs of it, but both of them involve drawing extra lines. Mancosu [22] p. 13ff quotes a tract of the 16th century author Pereyra, in which Pereyra uses the raf ${ }^{c}$ test to show that the extendibility of $B C$ to $B D$ is an accidental property of the triangle, and hence that the proof is not 'scientific'. (For Ibn Sīnā all scientific proofs are proofs of accidents - why should one bother to prove a definition? Also we will see in a moment why he believes that the rafc test doesn't give the answer that Pereyra claims.)

We turn to the cognitive part. According to Ibn Sīnā, our $b \bar{a} l$ (which I translated as 'mental processor' in (4) above) is the part of our mind where reasoning gets processed. From what he says about it, apparently it has a very limited range of actions: we send two ideas into the $b \bar{a} l$, and it either finds some overlap or similarity between the ideas, or it tells us they are incompatible. (So the $b \bar{a} l$ is basically a unification engine. In syllogistic reasoning it serves essentially the same role as unification in the resolution calculus. Obviously there has to be some other mental element that chooses the appropriate ideas to send into the $b \bar{a} l$; this raises some issues which are important for understanding Ibn Sīnā, but they are not our concern here.)

Ibn Sinna believes that the raf ${ }^{c}$ test involves a simple act of comparison between two ideas, with no further reasoning. So we do the test by a single pass through the $b \bar{a} l$. This is enough for the $b \bar{a} l$ to recognise the incompati- 
bility of $I$ and NOT- $J$ when $J$ follows from $I$ immediately:

There are accidents that are inherents of the whatness by a primary and clear entailment that is not mediated by any other accident. So when the entailment is not via some intermediate, it is impossible to negate the accident from the whatness at the same time as affirming the whatness, having them both enter the mental processor together. An example is [TRIANGLE] and [CAN IMAGINE A LINE OF THE TRIANGLE EXTENDED]. (Madkal [11] 35.18-20.)

But in a single pass, with no memory and no internal controls, the $b \bar{a} l$ has no way of recognising an incompatibility that depends on some intermediate that it hasn't seen:

It can sometimes happen that the holding of the accident is through something intermediate, so when this intermediate thing doesn't come into the mental processor, one can negate [the accident] — for example [one can negate] that any two angles of a triangle are [together] less than two right angles. (Madkal [11] 36.1-3.)

In short, the test of rafc (in the imagination) separates an idea $I$ from its accident $J$ if and only if $J$ is not an immediate consequence of $I$.

Somehow this theory is a little glib. There are signs that Ibn Sīnā himself has reservations about it. In Burhān [15] 38.3-8 he says that if a person didn't realise that all humans are rational, it would be possible for him to imagine there are humans with no sense of humour. Now Ibn Sīnā believes that [HAS A SENSE OF HUMOUR] is a consequence of [IS CAPABLE OF BEING SURPRISED], which in turn is a consequence of [RATIONAL] (e.g. Madkal [11] 30.1f). This is a two-step inference, so by the theory we have been reviewing, Ibn Sīnā should believe that it's possible, as things are, to imagine that there is a human with no sense of humour. So why does he introduce the desperate premise that the imaginer doesn't realise that humans are rational?

Nevertheless Ibn Sīnā is robust in his belief that there are non-constitutives that can't be removed in the imagination:

Pay no attention to the theory that says that non-constitutives (22) can legitimately be removed in the imagination. ('Išărāt i.12 [18] p. 49.) 


\subsection{Meanings of sentences}

Semantics is a theme that runs throughout the logical part of the Šif $\bar{a}^{\prime}$. But Ibn Sinna is probably not intending to make a contribution to general linguistics. His context is that we use logic to analyse arguments - other people's or our own. These arguments reach us in the form of sets of sentences. The sentences can even be written in a book, separated and in the wrong order, and with bits missing or added (Qiyās [14] 460.4-8). So we have to try to reconstruct the author's intentions. In other words, we have to reconstruct the 'reading' ('ak $\underline{k}$, literally 'taking') that the author put on his words. In this setting, Ibn Sīnā often refers to the kinds of information that we need to supply, and the ways open to us for finding them.

Of course this includes disambiguating both words and syntactic constructions. But as Ibn Sīnā often emphasises, it can also involve adding things that weren't explicit in the sentence:

... a time, or a place, or a comparison of how things are, or an implied event, or an action or an experience, or some consideration of possible versus actual, or some consideration associated with an agent or an experiencer .... (Easterners [17] 48.6-8.)

(The question how much interpretation we are entitled to add to a text was a hot topic in Qur'anic exegesis at the time.)

Thus every sentence has an indefinite number of possible readings. In general some of these readings will be true and some will be false. This is probably how we should understand Ibn Sīnā's notion of two sentences being 'true together', or 'agreeing in truth' (and likewise 'false together'). Thus a sentence $p$ and a sentence $q$ are 'true together' if there are a reading of $p$, and a corresponding reading of $q$, such that $p$ and $q$ are both true under these readings. This notion obviously depends on what we count as a 'corresponding' reading. But in fact Ibn Sīnā normally uses this notion of 'true together' for two sentences that are very close syntactically; for example they may differ only in their quantifier. If the reading provides references for the names in $p$, together with a place and time for the whole sentence, then the same references and place and time carry over directly to the other sentence.

Another notion in the same general area is 'îham, what a sentence suggests but doesn't in fact say.

But with propositions one should focus not on what they suggest

but on what they mean in themselves ( ${ }^{c} I b \bar{a} r a$ [13] 55.13f). 
Later in the ${ }^{c} I b \bar{a} r a$ ([13] p. 104) Ibn Sīnā uses this principle to dismiss the Grices of his time. He doesn't seem to have noticed that what the sentence suggests may be exactly the reading intended by the speaker or writer. This becomes highly relevant in paragraph [2.5.16] below; see the note on line 130.16 .

\section{Conflict and contrariety}

\subsection{Types of opposition}

The notions of two ideas 'agreeing' or being 'opposed' are two of the primitive notions of aristotelian logic. Since these notions are primitive, they tend to get short shrift in terms of definitions and explanations. But we do meet classifications of different types of opposition.

For Ibn Sīnā the general term for 'opposed' is muqābil, literally 'facing'. He does offer a definition of this in Maqūlāt [12] 241.7f:

We say: opposing pairs are those which don't combine in a single subject from a single aspect at a single time together.

Unfortunately we have to guess the meaning of 'combine'; but almost certainly he means 'are true together' as in $\S 3.3$ above. We also need to know what 'aspects' are; I ignore this here. I think we have to read 'single subject' in a rather forced way as 'the same singular subject', for example 'Zayd'. Thus [MOVING] and [AT REST] are opposed, because for example the following sentences can't both be true at the same time with the same Zayd:

Zayd is moving. Zayd is at rest.

Ibn Sīnā's definition seems to apply only to noun-type ideas; but we can extend it to sentence-type ideas by regarding these as classifiers of times and/or circumstances. This reduction of sentence-type ideas to noun-type ideas runs throughout Ibn Sīnā's logic, though as a heuristic principle rather than a formal reduction.

Ibn Sīnā mentions three main types of opposed pairs: negations (salb), contradictions (naqied) and contraries (didd). Negations are got by adding or removing a particle of negation, provided of course that it applies to the whole idea.

When the predicate is negated on its own without negating the quantity with which it is predicated [i.e. the quantifier on the subject], then the negation is not a negation of what was affirmed ( ${ }^{c}$ Ibāra [13] 94.4-6). 
In practice contradictories are the same thing as negations, though Ibn Sīnā may intend the contradictory of $p$ to be by definition a sentence which is true exactly when $p$ is false (i.e. under the same readings).

There is some discussion of contraries in book 7 of Maqūlāt. Ibn Sīnā mentions a number of pairs which are generally considered contrary. They include [HEAT] and [COLD], [HEALTH] and [SICKNESS], [MOVEMENT UP] and [MOVEMENT DOWN]. He discusses which of these pairs can be described by saying that some particular idea is present on one side and absent on the other. If he has a general definition for 'contrary' here, I haven't found it. But in ${ }^{c} I b \bar{a} r a$ he gives the classical definition for the case of sentence-type ideas:

Let us call this opposition 'contrariety', where the two opposing things don't ever agree in truth, but they do agree in falsehood. ... Contraries can't be true together, but they can be false together, as you know. ([13] 46.16-47.2.)

Just before giving the definition, he has quoted the example pair

Each person is a writer. No person is a writer.

He says the second sentence is got from the first by negating the predicate; so he is not distinguishing the second sentence from 'Each person is not a writer'.

\subsection{Aristotle's question in PH14}

Ibn Sīnā opens his commentary on PH14 with a remark that the passage is about the relation 'in greater conflict with' ('ašadd 'inād). This reading can be traced back at least to Ammonius (mâllon mákhesthai, [3] p. 252, 202r12), who led the Alexandrian school in around AD 500, and it survives down to Whitaker ('more violently opposed', [27] p. 172). But the evidence to support it is vanishingly small. In both the original Greek and 'Ishāq's Arabic translation, the comparatives are limited to just a few lines (23b2024 , a small part of what I called Step 4 a in $\S 2.3$ above). But for reasons given in $\S 2.2$ above, I don't think Ibn Sīnā is much concerned about whether he has interpreted this particular passage as Aristotle intended it.

We don't know specifically that Ibn Sīnā knew Ammonius' commentary. But it's likely that he did, since some half a century earlier Yahyā ibn ${ }^{c}$ Adi [28] pp. 321-3 regarded the views of the 'Alexandrian commentators' on PH14 as something to discuss between friends. I thank Peter Adamson for this reference. 
The relation 'in greater conflict with' is a rather strange one to find in an aristotelian logical treatise. It has three variables: $X$ is in greater conflict with $Z$ than $Y$ is. Most aristotelian logicians found it beyond their capabilities to handle even a relation with two variables. Ibn Sīnā himself has an ambivalent attitude to variables in relations. Throughout his logical writings he calls attention to them, and particularly to the need to supply the assumed parameters when we interpret sentences. But his formal logic avoids them completely. There has to be a reason for this discrepancy. I think it's Top-Level Processing again; for further details see [9].

The word 'inād 'conflict' never appears in 'Ishāq's translation of PH14, though muqābil, salb, naqīd and didd 'contrary' are all frequent ([19] — ${ }^{c}$ inād does appear at 21a38, earlier in the Perì Hermēneías). I suspect Ibn Sīnā chooses a word distinct from all of these four, and uses it throughout his commentary, in order to make it clear that he wants to visit a new question. In PH14 one easily gets the impression that Aristotle is reworking issues that he has forgotten he settled earlier. ('The body of the chapter ... upsets the distinction between contraries and contradictories which was drawn in Chapter 7', Ackrill [1] p. 153.) The notion of ${ }^{c}$ inād turns up again quite often in Jadal [16], Ibn Sīnā's commentary on Aristotle's book about debate. Ibn Sīnā says in [2.5.1] that the topic of PH14 has more to do with debate than with logic; but I don't think the question of 'greater conflict' reappears in Jadal.

\subsection{The quickest contradiction}

Ibn Sīnā's interpretation of Aristotle's text seems to rest on two intuitions, which we can call Canonicality and Immediacy.

Canonicality is the intuition that if every proposition has a unique most conflicting opposite proposition, then there has to be a recipe for finding this most conflicting opposite which is uniform across all propositions.

A simple application of this intuition is to think of an idea $I$ in terms of its extension $\bar{I}$, which is the class of things that satisfy $I$. Suppose $\Omega$ is the relevant universe of things. An idea $J$ is contrary to $I$ if and only if $\bar{J}$ is a subclass of $\Omega$ that is disjoint from $\bar{I}$. Just from the given data, how can we define a particular contrary $J$ for $I$ ? There are only two options: $\bar{J}$ must be either the complement of $\bar{I}$ in $\Omega$, or the empty class. Aristotelian logicians are unsure whether there are ideas with empty extension; and in any case there are undesirable consequences if two different ideas have the same most conflicting opposite. This leaves only the idea NOT- $I$, whose extension is the unique contrary of $\bar{I}$ that includes the extensions of all other 
contraries of $I$. This is the argument of [2.5.5], and similar thoughts lie behind [2.5.4], [2.5.9], [2,5,14] and [2.5.17].

Immediacy is the intuition that if the incompatibility of $I$ and $K$ can be proved more briefly than the incompatibility of $J$ and $K$, then $I$ conflicts with $K$ more strongly than $J$ does.

The simplest example of this is where the only way to prove the incompatibility of $J$ and $K$ is by using the incompatibility of $I$ and $K$ as a lemma. Ibn Sinnā isolates this case at [2.5.6]. Also if the incompatibility of $I$ and $K$ can be proved using only ideas in the essences of $I$ and $K$, whereas to prove the incompatibility of $J$ and $K$ one needs to go outside the essences, then prima facie one expects that the proof will be shorter for $I$ than for $J$. This seems to be the intuition behind [2.5.11]-[2.5.13].

In $\S 3.2$ above we saw how Ibn Sīnā has reasons for being interested in lengths of proofs. The idea of grading contradictions as more or less lethal has some echoes in modern work; it can matter in databases.

Another area where people have considered false theories and classified them in terms of distance from truth is the philosophy of science, as for example in Oddie [23]. I thank Sjoerd Zwart for making me aware of this possible parallel, though I have to add that I think it would take some ingenuity to make Ibn Sīnā's suggestions relevant to the questions discussed by Oddie.

\section{The 'well-known commentator'}

\subsection{Ibn Sīnā's outrageous analysis}

In paragraph [2.5.16] Ibn Sīnā attributes the following argument to an unnamed commentator:

A contradictory belief can be found for a true belief in each case.

(30) This fact is something essential, since an essential thing is a thing that is found in all cases.

Ibn Sīnā seems to take the argument as follows. Writing

$C x: x$ is the property of a thing, that true beliefs about it have contradictories.

$E x: x$ is essential.

$A x: x$ is found in all cases.

Then Ibn Sīnā reads the syllogism as follows:

Every $C$ is an $A$. Every $E$ is an $A$. Therefore every $C$ is an $E$. 
I am guessing at some details of (31). But the formal argument (32) can be read off from Ibn Sīnā's discussion.

This argument (32) is obviously invalid. Ibn Sīnā could demonstrate this in a couple of lines by giving interpretations of $C, E$ and $A$ that make the premises true and the conclusion false, following Aristotle's procedure in the Prior Analytics. But this is not what he does.

What follows calls for some knowledge of syllogisms and their metatheory. A good source for this material is the first three chapters of Thom [25]. Note that for Ibn Sīnā a syllogism strictly consists of just the two premises; hence he has only three figures, which are distinguished by where the middle term lies.

Ibn Sīnā assumes that (32) is intended as a syllogism. He reasons, assuming for contradiction that the syllogism is valid:

(a) (130.3) The conclusion is universally quantified.

(b) By (a), the syllogism is not valid as a third figure syllogism.

(c) (130.6) The conclusion is affirmative.

(d) By (c), the syllogism is not valid as a second figure syllogism.

(e) (130.4) By (b) and (d) the syllogism must be in first figure.

(f) By (e), the subjects of the premises are respectively the middle term and the minor term.

(g) (130.5) By (f), $E$ must be either the middle term or the minor term.

(h) (130.1f) If $E$ is the middle term then it isn't in the conclusion.

(i) (130.7) $E$ is in the conclusion.

(j) By (h) and (i), $E$ is not the middle term.

(k) (130.7f) By (e), if $E$ is the minor term then it is the subject of the conclusion.

( $\ell$ ) (130.8) $E$ is the predicate in the conclusion.

(m) By (k) and $(\ell), E$ is not the minor term.

(n) By (g), (j) and (m), contradiction. 
Ibn Sīnā leaves to the reader the steps for which I give no line reference. In fact we could have stretched out the argument still further by including the metatheorems that Ibn Sīnā uses but doesn't state. Recall §2.2!

But Ibn Sīnā has only just started his demolition. He moves on to consider a possible repair of the syllogism:

(o) (130.10) Suppose we replace the premise 'Every $C$ is an $A^{\prime}$ by 'Every $A$ is a $C^{\prime}$.

(p) (130.12) Then we get a valid syllogism with conclusion 'Every $E$ is a C.'

(q) (130.11) But our new premise is false, and our new conclusion is not what was claimed.

(r) (130.13) In any case the commentator has forgotten to include the universal quantifier on this premise.

Next he reverts to the original syllogism.

(s) The middle term is predicate in both premises.

(t) (130.16) By (s), the syllogism is in second figure.

(u) (130.15) Both premises are affirmative.

(v) No valid syllogism in second figure has both premises affirmative.

$(\mathrm{w})$ By $(\mathrm{t}),(\mathrm{u})$ and $(\mathrm{v})$, the syllogism is invalid.

Ibn Sīnā has already shown this result, but this time he is using a different metatheorem (v).

Finally he tries another repair:

(x) (130.16) Suppose we replace the premise 'Every $E$ is an $A^{\prime}$ by 'Every $A$ is an $E^{\prime}$.

(y) (130.16) Then we are using an obviously false premise.

On the basis of the facts that Ibn Sinnā gives us, this final repair is pretty clearly what the unnamed commentator intended in the first place. So a final twist of the knife is that Ibn Sīnā doesn't even bother to acknowledge that the resulting syllogism is a straightforward instance of the valid first figure mood Barbara. 
The premise 'Every $A$ is an $E$ ' says 'A thing that is found in all cases is essential'. This is a tolerable statement of the Eisagogge view of essence and accidents; see $\S 3.2$ and the note on line 130.16 below. Ibn Sīnā rejects this reading because he rejects the Eisagogge view. But this could be a difference of terminology between Ibn Sīnā and the unnamed commentator, not a mistake by the commentator. Ibn Sīnā also refuses to consider the possibility that the commentator's final clause could be read as an equivalence between $C$ and $E$; see the note on 130.16. So Ibn Sīnā's whole attack on the commentator is almost certainly based on a wilful misinterpretation of what the commentator said. This was hardly a new technique of debate, but the crudity of Ibn Sīnā's use of it can only be seen as undisguised personal malice.

\subsection{Why?}

Ibn Sīnā's procedure in demolishing the unnamed commentator does have another striking feature. He is conducting a philosophical debate by using a number of metatheorems of syllogistic logic. More precisely he is using metatheorems of the form 'Any valid syllogism must satisfy the following condition ...'. Let us call these NCV (Necessary Conditions for Validity) metatheorems.

The chief accepted use of logic in Ibn Sīnā's time was to check arguments by reducing them to syllogistic form. For this one would need to know the rules of syllogisms. But here Ibn Sīnā is using not those rules but higher-level rules about them. Perhaps he was the only logician of his age who was capable of deploying these metatheorems to make a philosophical point; if he believed he was, he certainly wouldn't have wanted to keep the fact to himself. But we have no reason to deny him credit for his observation that NCV metatheorems are useful.

The metatheorems that he invokes here are not very novel - I think they can all be found in Aristotle. Among the other known results in Ibn Sinnā's time, the only other NCV metatheorem that I can offer for comparison is Theophrastus' peiorem ('worse') rule, which said that on any of several measures of strength, the conclusion of a valid syllogism can never be stronger than the weaker of the two premises. (Thom [26] pp. 23, 76.) But this rule was imprecise and it didn't generalise beyond categorical syllogisms - as noted in Thom's book, there is a counterexample in Ibn Sīnā's modal syllogisms. (Ibn Sīnā gives his own version of the rule at Qiyās [14] 108.9, where 'ahsan 'better' is clearly a corruption of 'akass 'worse'!) By contrast the NCV metatheorems that Ibn Sīnā uses in his commentary are 
ones that he had checked for himself in a range of extensions of categorical syllogisms.

Within a couple of centuries of Ibn Sīnā, versions of the laws of distribution started to appear in the West. These laws are NCV metatheorems. The best versions were more precise than the peiorem rule, but still there were problems about generalising them beyond categorical syllogisms. These problems were resolved only in the late twentieth century. Meanwhile in 1906, in one of his most perceptive papers, Frege [7] had argued that the logic of his time had no sound basis for proving general NCV metatheorems, and that such a basis would need to be found if Hilbert's arguments for the independence of the parallel postulate were to be put in an acceptable form.

\subsection{Who was the 'well-known commentator'?}

Ibn Sinna often discusses the views of other commentators, but he rarely names them except by epithets like 'well-known'. In the present case Fritz Zimmermann (personal communication) has suggested that it might be Abū al-Faraj ibn al-Tayyib, a contemporary of Ibn Sīnā who did write a commentary on the Perì Hermèneías.

If Zimmermann's suggestion is right, the passage we are discussing falls neatly into line with an episode that Gutas discusses ([8] pp. 64-72). The episode took place in 1030, some half dozen years after Ibn Sīnā wrote his own commentary on Perì Hermēneías. According to an anonymous disciple of Ibn Sīnā, someone suggested to Ibn Sīnā that he might not be up to date with contemporary philosophy. Ibn Sīnā took umbrage, and sent one of his friends off to Baghdad with instructions to buy the latest books in the field. There Ibn al-Tayyib had some commentaries for sale; but when Ibn al-Tayyib heard that it was Ibn Sīnā who wanted the books, he 'asked an exorbitant price', which was duly paid. Later Ibn Sīnā let it be known that in spite of paying the price, he had already formed a low opinion of Ibn al-Tayyib. In his account of the episode, the anonymous disciple goes on to include Ibn al-Ṭayyib among people who

never acquired the habit of dealing with [the forms of syllogisms] and they never suffered the pains of analyzing the details of problems so that they may gain a syllogistic habit; their sole reliance, instead, is upon ideas not subject to rules. ([8] p. 69.)

If Ibn al-Ṭayyib was indeed Ibn Sīnā's 'well-known commentator', then we can easily understand why he didn't want Ibn Sīnā to buy copies of his 
later writings.

The anonymous disciple lists those of Ibn al-Tayyib's commentaries that 'became available to us', and he includes the Perì Hermenneias commentary. If this wording means that Ibn Sīnā didn't have Ibn al-Tayyib's Perì Hermēneías commentary before 1030, then Ibn al-Tayyib can't be the well-known commentator. But the wording might only mean that the list contains those commentaries that were available after the 1030 purchase, including some that Ibn Sīnā already had.

If we had the commentary then we could see whether it contains the argument that Ibn Sīnā complains of. Unfortunately it survives only in three copies of an epitome, all in India; Lameer [21] p. 96 reports their coordinates. This epitome is our best hope for settling whether Ibn Sīnā's target was Ibn al-Tayyib. My attempts to see one of the copies (Calcutta, Būhār Library, Arab. Logic 283, fols. 44-7932) haven't so far borne fruit.

But did Ibn al-Tayyib in fact accept Porphyry's account of essence and accidents? Apparently yes. We have his commentary on Porphyry's Eisagō$g \bar{e}$, and in it we find for example a description of accidents as things which

when they are removed (irtafac $a$, from rafc) don't affect the essence of the thing ([10] p. 1391.11$).$

But probably there were other philosophers who followed Porphyry in this. The anonymous disciple quotes Ibn Sīnā as naming two other contemporary philosophers who 'adhere more closely than others to the [traditional] transmission of certain books' ([8] p. 68).

\section{Translation}

The text is taken from section 2.5 of [13], a volume of the Cairo edition of Ibn Sīnā's Šifā'. Reference 124.5 means line 5 on page 124. The division into paragraphs [2.5.1] etc. is my own. For transliteration of Arabic words I follow Wehr's Dictionary.

An explanation of whether the opposition between affirmative and negative is greater, or the opposition between two affirmatives whose predicates are contraries. 
[2.5.1] It has been customary to conclude this part of Logic with something that logicians as such don't need. In fact it is more closely related to investigations in the form of debate. Namely: when a predicate is predicated of a subject - and this predicate has a contrary - which is in greater conflict with [the predication], the affirmation of the contrary, or its negation which is its contradictory opposite?

For example when someone says

Zayd is just.

and we say

Zayd is unjust.

is it (36) that is in greater conflict with (35), or is it the sentence

$$
\text { [Zayd] is-not just? }
$$

And if we say

$$
\text { Everybody is just. }
$$

is it the contrary of this when we say

(39) Everybody is unjust.

or is [the contrary] what was mentioned earlier, namely

(40) Not a single person is just?

This is stuff for sects to quarrel about, but the truth of it is that his being unjust is in the nature of things more strongly in conflict with his being just than is his not being just.

[2.5.2] As concerns [the conditions for] assenting [to a proposition], and the force [of the proposition], regardless of whether [the proposition is taken to be] a belief or a verbal expression: the negative form [of the proposition] conflicts most strongly with the affirmative form and is furthest from matching it in truth and falsehood. The present investigation is about the force, and the force can be [taken] either as a phrase or as a belief (because the phrase follows the belief). So let us carry out the investigation of these conflicting [propositions] in terms of beliefs.

[2.5.3] Consider a belief about something good, namely that it is good, 
and a belief that it is not good, and a belief that it is bad. You should know that if the belief is associated with two contrary [predicates], as when we believe that Moses is good and that Pharaoh is bad, or with two mutually contradictory [predicates], as when we believe that Moses is good and Pharaoh is not good, this doesn't imply that the two beliefs conflict with each other. For the two beliefs to negate each other, they would have to be about a single subject.

[2.5.4] So suppose we consider the truth about one subject, namely that he is good. If it is believed that he is bad, and it is also believed that he is not good, which of the two beliefs is in itself is more strongly in conflict [with his being good]? The only thing that makes it impossible to believe that [the subject] is both good and bad is that a bad thing is not good. If in place of 'bad' we have 'thing that is not good and not bad', then it would still be impossible to believe that [the subject] is good and not good. In fact there are many things that are neither good nor bad. It's clear that the conflict in the case of the first belief [(that the subject is bad)] is not because the two believed things are contrary to each other, but because the contents of the two beliefs deny each other. Denial is in the first instance between an affirmation and [the corresponding] negation.

[2.5.5] They say: Another piece of evidence for this is that when a thing is good and just, some affirmatives are true of it, for example that it is praiseworthy and preferable, and so are some negatives, for example that it is not blameworthy and not loathsome; and some affirmatives are false of it, for example that it is loathsome and blameworthy, and some negatives are false of it, for example that it is not praiseworthy and not preferable. Now being a genuine contrary [of $X]$ is not something that one can impose on everything that disagrees [with $\mathrm{X}$ ] this way or that. In fact a single thing has just one genuine contrary. It follows that the contrary must be one of these [disagreeing things] that includes them all. So it includes all the affirmatives and the negatives which say falsely of the good thing that it is not good. Any [idea] - whether it affirms or negates - which is legitimately taken as [NOT GOOD] is inconsistent [with [GOOD]], and [NOT GOOD] itself is inconsistent with [GOOD] even if it is not considered to be one of those [disagreeing things].

[2.5.6] Suppose a thing $X$ can be distinguished from a thing $Z$ without needing another thing $Y$, whereas $Y$ can't be distinguished [from $Z$ ] without [using the distinctness of] $X$ [from $Z$ ]. Then $X$ has a distinctness [from 
$Z$ ] which is prior [to the distinctness of $Y$ from $Z$ ]. A thing that has a distinctness [from $Z$ ] that is prior [to all other distinctnesses from $Z$ ] is most strongly in conflict [with $Z$ ]. So the negation [of $Z$ ] is most strongly opposed [to $Z$ ], and what is most strongly opposed [to a thing] is the contrary [of the thing], so the negative [of $Z$ ] is the contrary [of $Z$ ].

[2.5.7] It's plausible that these two paragraphs in the First Teaching were not intended to be an argument at all, and that the aim in the first of the two was just to indicate that a contrariety in things doesn't itself entail a contrariety in beliefs, but rather a contradiction in things is a necessary condition for having a contrariety in beliefs.

[2.5.8] And the aim of the second paragraph is to indicate also that when beliefs are mutually incompatible, even though the beliefs can't be true together, it doesn't show that they are contraries. So, to spell this out, there are infinitely many things which are legitimately denied of a person who is good and just. For example he is not a bird or a stone or the sky; to assert any of these [of him] is false. Also there are infinitely many things which it would be legitimate to assert of him, for example that he is white and he is sitting and he is acting, so it is false to deny that these things could be true of him. It's impossible for infinitely many things to be true of him, but infinitely many things are false of him. It's not appropriate to consider in each case whether or not the belief is contrary to the belief that he is good — this applies to infinitely many beliefs.

[2.5.9] But this enquiry is just about things which already had some befuddlement in them, and this befuddlement lies just in what a thing can become. Thus, granting that a good person is not a bird, and is also not bad, so that both [BIRD] and [BAD] are false of him, still he could become one of these things, but he couldn't become the other. Of the two things that are opposed [to [GOOD]], the one that he can become is [BAD], and the one that he can't become is [BIRD]. The befuddlement is just about things opposed to [GOOD], like [BAD] and [UNJUST], namely whether the belief that he is just is contrary to the belief that he is bad and unjust. This fits what is said in the First Teaching, which aims to make a facilitation and to indicate that beliefs which deny [other beliefs] are not always opposed [to them] in the sense of contrariety. Otherwise we would be dealing with the befuddlement that the belief that Zayd is just will be contrary to the belief that he is a bird - and in fact contrary to infinitely many other beliefs.

[2.5.10] It's plausible that the aim of the First Teacher was what we indi- 
cated. What he put at the beginning of this topic was put there not as an argument but as a facilitation. After finishing this statement of his intentions, he starts by claiming that he has established [firstly] that the contrariety of two things doesn't itself make the two [corresponding beliefs] to be contrary to each other, and [secondly] that the fact that two beliefs negate each other doesn't force the two [corresponding] things to negate each other. So he has to undertake an investigation of the former point which is more specific than the investigations of these two points.

[2.5.11] So we say: In fact when we say 'it is good' of whatever is good, we speak truly, and when we say 'it is not bad', we speak truly. But the truth that we express about [whatever is good] by saying 'It is good' is a self-contained truth in the essence (of [GOOD]), whereas the truth that we express about it by saying 'It is not bad' is not in the essence (of [GOOD]). [GOOD] is in the essence of [GOOD]. But as for [NOT BAD], that is an accident of [GOOD] [which becomes known] when [GOOD] is opposed to something that is not its essence and is distinct from its essence, namely [BAD], so that [BAD] is denied of [whatever is good]. So the assertion that [whatever is good] is good is completed for [GOOD] through the essence of [GOOD], while its denial is completed for it only through something else. You already know that the negative inherents in cases like this are not internal to the essence. And corresponding to these two truths are two falsehoods. It is false that [whatever is good] is not good, and this is a falsehood that is opposed to [GOOD] in its essence. And it is false that [whatever is good] is bad, and this is a falsehood that is opposed to something that is an accident of it. And when the belief that [something good] is good is true in an essential feature, [and] while the belief that [something good] is not bad is true in an accidental feature, a belief that [something good] is not good is false in an essential feature. Falsehood about something in the essence is more opposed to truth about something in the essence than falsehood about some accident is. This is how one should say it.

[2.5.12] About the belief that one of two [falsehoods can be] more strongly false than the other: this [belief] is incorrect. There is no truth that is more strongly true than some [other] truth, nor is there any falsehood that is more strongly false than some [other] falsehood. However, some truths are more permanent and some are less permanent. Also some truths are about an essential matter while others are about a nonessential one. A falsehood about an essential matter is more strongly in conflict [with the truth]. 
[2.5.13] This could give rise to another argument that should be understood as follows. Suppose there is a just person that I know, and after checking it explicitly I believe that he is good. Then there is no need to believe at the same time that he is not bad, since this is not in his essence; rather it is an accident of him. But for a thing in the essence to come into the mental processor, there is no need at all for it to refer to a relation to something external [to the essence]. Rather, the essential truth simply coalesces as a result of the the subject and the predicate coming into the mental processor, whether or not anything else is brought into the mental processor as well. And if I were to introduce two [other] beliefs that oppose this belief, namely that he is bad and that he is not good, I would find that the belief that he is bad is not complete for me unless it contains [the belief] that he is not good. A falsehood which is opposed to an accidental truth is completed only by an essential falsehood coming into the mental processor. So if it doesn't come into my mental processor, about the just person whom I know to be good, that he is not good, then it is not possible for me to believe that he is bad. And this is because I know and believe that this just person is good, and that this is true. If I think of him as bad, so as to test this opposition, there comes into my mental processor the compulsion to negate this truth about him - [though conversely] when the negation of this truth comes into my mental processor, it doesn't have to have already come into my mental processor that he is bad. [Aristotle's] indication has to be understood in this forced way. Although it is not quite right, it is close to what we said in the first place; it amounts to the same thing.

[2.5.14] Here is another argument. All propositions have opposites in the form of their contradictory negations. But not every proposition has an affirmative opposite that expresses its contrary. In fact when we say "Suchand-such is square", facing it we [may] find that it's not square, though we don't find that it's some other kind of shape which is contrary to square. In this case the thing that conflicts [has to be] the negative, and not an affirmative predicate which is contrary [to 'square']. When a proposition has an affirmative contrary, it still has a negation that conflicts with it. Thus every affirmative proposition has a negation that conflicts with it, while not every affirmative proposition has a conflicting [proposition] that is affirmative. Just by being affirmative, an affirmative proposition has a conflicting proposition that is negative; the other conflicting [proposition] arises incidentally and not from the affirmativeness [of the first proposition]. 
every affirmative there is an affirmative that conflicts with it in the way that [REST] conflicts with [MOVEMENT] taken absolutely. Rather it can be assumed that the negation gives the most general and greatest conflict. But take the case where an affirmative which is contrary to a given predicate is narrowed down so as to stay affirmative. Is there a contrary which results from narrowing down [the predicate] over against it, and which is more strongly contrary to it? Thus when [MOVEMENT] is specified to be [DOWNWARDS MOVEMENT], the contrary to it [(namely [UPWARDS MOVEMENT])] is a movement which conflicts with it more strongly than [REST] does.

[2.5.16] But consider the case of a certain well-known commentator and all those people who come close to his level of deficiency. He supports this argument by the following unsound syllogism:

A contradictory belief can be found for a true belief about any

(41) thing. This is an essential thing, since an essential thing is a thing that is found in all cases.

See the mistake he made in the syllogism. He produced the phrase

since an essential thing is found in all cases

as a premise for a syllogism that concludes:

(43) This is an essential thing.

This goal of his is universally quantified with a singular subject, [and the conclusion is affirmative], so that it can only follow in the first figure. So he can only put 'the essential' in (42) as either the middle term or the minor term, because it is the subject in this premise [[...]]. If he put it as the middle term, then it shouldn't occur in the conclusion, but he did make it occur there. If he put it as the minor term then the conclusion would be

(44) The essential is such-and-such.

not that such-and-such is essential. So in fact 'the essential' has to be the minor term in the syllogism, not the major.

When we take into account the other premise, we find that what this premise shares [with the first-mentioned premise] is the property 'found in all cases'. Suppose we make that the subject there, so that the inference is as follows: 
The essential is what is found in all cases.

(45) What is found in all cases is that a true belief has a contradictory opposite belief.

Then - disregarding the fact that the major premise is false when 'found in all cases' is taken in it in the same sense as in the minor premise - it is entailed that the essential is such-and-such, not that such-and-such is essential. Besides being false, the [major] premise was misstated; for the syllogism to have a valid conclusion, the premise is taken as universally quantified, not as unquantified.

And if he made 'found in all cases' the predicate rather than the subject, as indeed he should, then [the syllogism would be]

That a true belief has a contradictory opposite belief is a thing (46) found in all cases.

The essential is what is found in all cases.

so he would have made a deduction from two affirmatives in the second figure!

If he had converted [the first premise], he would have made it

(47) Anything found in all cases is essential.

But this is obviously false.

[2.5.17] After this argument there comes a strong argument. It says that 130.17 when something is not good and we believe that

(48) It is not good.

the only other beliefs (of the kind relevant to this discussion) that we can introduce in contrast to (48) are the beliefs that

(49) It is bad,

that

(50) It is not bad

and that

(51) It is good. 
But there are many cases where a belief that it is bad can be true together with the belief (48), so (49) will not be an absolute opposite of the belief (48). Also our belief (50) that it is not bad can be true [together with (48)]. In fact we [can] find an individual thing, for example an infant, that is neither good nor bad. Likewise [we can find something that is] intermediate [between good and bad]. The remaining case is that the belief which conflicts with [its being not good] is (51) that it is good. Therefore the belief that it is good conflicts with the belief that it is not good, and is the genuine contrary of it. A contrary is the contrary of its own contrary. So what conflicts with the belief that it is good is that it is not good. In fact it's impossible for $X$ to be the genuine absolute contrary of $Y$ when $Y$ is contrary to something other than $X$.

[2.5.18] If we put the [same] question about a universally quantified sentence, we will be asking whether what conflicts with the sentence

(52) Every human is not good.

is the sentence

(53) Every human is bad.

or the sentence

(54) Every human is not bad.

or the sentence

(55) Every human is good.

The contrary of (52), in the sense [of 'contrary'] that we have explained, is (55). So the contrary of the sentence (52) is the sentence (55), whereas the contrary of the sentence (55) is the sentence

(56) No person is good.

which denies of each individual that he is good. This same account applies to both singular sentences and universally quantified ones. But as for unquantified sentences, how could they be contrary to each other, given that they are true together? Likewise with two existentially quantified sentences. Contraries, even though they can be denied together and false together, can't be true together. 


\section{Notes}

[2.5.1] This comments on Perì Hermèneías 23a27-32.

124.8 'is-not just'. Arabic uses a single word for 'is not'. This precludes the reading 'is not-just', which Arabic would express differently.

124.10 'mentioned earlier': Probably this refers to those places where Ibn Sīnā has said that a definition is a conjunction of genus and differentiae, for example (14). It seems absurd to invoke this fact, when the differentiae can contain any number of negations. The explanation is almost certainly the principle of Top-Level Processing, $§ 3.1$ above.

[2.5.2] This comments on Perì Hermēneías 23a32-39.

124.12 'force' (hukm): This very common word has a rather diffuse meaning. Possible translations range between 'judgment', 'content', 'force', 'logical properties' and 'the rules for using it'.

124.12 'negative form' (sālib): Ibn Sīnā sometimes writes as if the negation of an idea $X$ is the same idea $X$ but taken 'negatively'. Add to this that he sometimes speaks of noun-type ideas as 'affirming' or 'negating', as at 125.16. The outcome is that his words for 'negation' and 'negative' don't always translate smoothly into modern logical idiom.

[2.5.3] This comments on Perì Hermēneías 23a39-23b7.

[2.5.4] Here Ibn Sīnā gives his own broad take on the question.

125.9 'the two believed things': Apparently not the two beliefs mentioned in 125.6, but the first of those beliefs together with the supposition (from 125.5) that the subject is good.

[2.5.5] This doesn't fit anything in Perì Hermēneías closely, though there might be a reminiscence of 23b7-13. But the 'They say' at the beginning is probably meant to indicate that Ibn Sīnā is commenting on some other commentator. A likely source is Al-Fārābī [2] 201.21-202.6. Thus:

If the contrary is to be an affirmation, it must be the one that embraces (taštamil ${ }^{c}$ ala $\overline{\text { }}$ ) all the false affirmations; and if a negation, the one that embraces all other false negations ([29] p. 195). 
125.15 'includes' (yac umm): One of the primitive notions of Ibn Sīnā's logic, so that he never defines it. What he says about it is consistent with the following definition: idea $A$ includes idea $B$ if and only if for every idea $C$, if $B$ is true of $C$ then so is $A$. Al-Fārābī has ' $a^{c} a m m$ in a corresponding place ([2] 202.3,5).

125.17 '[NOT GOOD]' ('ammā laisa bi-kair nafsuh): The expression 'ammā 'as for' is normally followed by a noun phrase in the nominative. So it is here, when we note that nafsuh and similar expressions can serve as indicators that Ibn Sīnā is referring to an idea. Then bi-nafsih later in the line picks up the other relevant idea, namely [GOOD].

126.1 'it is not considered': Ibn Sīnā has said first that [NOT GOOD] is itself an idea that is inconsistent with [GOOD], and second that it includes every such idea. That seems to complete the argument, so perhaps we should delete the pointless clause 'even if ...'. A suspect feature of the clause is that it finishes with tilka; this is uncommon but not unique, see for example [15] 20.19 and 22.4.

[2.5.6] This again is pure Ibn Sīnā. It seems to complete the argument of paragraph [2.5.4].

126.1 'a thing $X^{\prime}$ : Here we see the three variables of the relation ' $X$ is more strongly in conflict with $Z$ than $Y$ is'. But none of them appear as variables in Ibn Sīnā's text. Thus $Z$ is mentioned only by implication; $X$ and $Y$ are introduced briefly as 'the thing' and 'the other', and there is just one anaphoric pronoun referring back to 'the thing'. After a career teaching logic, I lay a heavy bet that only a fraction of Ibn Sīnā's readers reconstructed all the cross-references correctly.

Why did he do this? Even if he didn't want to use variables here, he could have clarified matters hugely by introducing a 'first thing', a 'second thing' and a 'third thing' and cross-referencing properly. One suspects he wanted to make a point. Maybe it was that logic takes no prisoners. More likely it was that in interpreting anybody's statements you need to supply what the speaker assumes about other entities besides those that are mentioned explicitly; cf. (23) in $\S 3.3$ above.

[2.5.7] This comments on Perì Hermèneías 23b13. 
126.4 'the first': The 'first paragraph' is 23a32-23b7. But Ibn Sīnā has already extracted a sound point from this paragraph in his own paragraph [2.5.2].

[2.5.8] This comments on Perì Hermēneías 23b7-13.

126.7 As proposed by Moktefi, read tanäfin for yunāfì, and wa-in for wa-an at the beginning of the next line.

126.11 'impossible for infinitely many things':

Also it is said [in the First Teaching] that only finitely many predicates are internal to the whatness of a thing, because these [predicates] are internal to the defining of things, ... So if definitions were to reach the point that there were infinitely many things in them, then it wouldn't be possible for us to define anything. But definitions do exist, since things get conceptualised. So they must have finitely many principles. (Burhān [15] 168.6-9.)

This paraphrases Aristotle Posterior Analytics A22 82b37-39.

[2.5.9] This comments on Perì Hermēneías 23b13-15, and perhaps also 23b2123.

126.14 'befuddlement': Aristotle himself mentioned befuddlement (or more strictly deception, apátē) and becoming (genéseis). It seems nobody has a convincing explanation of what Aristotle had in mind here. Ackrill [1] doesn't attempt to explain it. Apparently the idea of mentioning something that Zayd couldn't become (namely a bird) is Ibn Sīnā's own. Readers will certainly notice that [BIRD] conflicts with Zayd's essence, whereas [BAD] doesn't. From the arguments to come in [2.5.11] and [2.5.12], this should suggest that [BIRD] is a better candidate for the contrary of [GOOD] than [BAD] is. But this conclusion doesn't fit with anything else in PH14, so Ibn Sīnā leaves it to the reader to spell out.

127.3 'facilitation': The word is tawti'a, as in line 127.7 below. But here Ibn Sīnā adds 'indication' (tanbīh). This word belongs to one of the standard excuses for Aristotle, namely that sometimes he gave only hints, so as to protect his teachings from the intellectual riffraff. Cf. Gutas [8] pp. 307-311, noting that tanbih is the word translated as 'reminder' on his p. 310. 
[2.5.10] This comments on Perì Hermēneías 23b2-7.

127.9 '[secondly] ...': The point seems to be a gratuitous contradiction of $126.6 \mathrm{f}$ above. Probably the text is faulty.

[2.5.11] This comments on Perì Hermēneías 23b15-21.

127.10 'So we say': This is Ibn Sīnā's standard formula to indicate that he has been laying out a problem and he is about to give his own solution. This paragraph doesn't seem to reflect Ibn Sīnā's own views any more than, say, [2.5.4]. Maybe he is signalling that he thinks the argument in this paragraph is the heart of the matter.

127.10 'it is good': Aristotle talks of beliefs about 'the good', which he makes neutral (estìn agathòn). Arabic has no neuter case, so Ibn Sinnā has a choice between reading the corresponding word (alkair) as 'the good person' or 'the good thing', or simply as 'the good'. (Cf. Ackrill [1] p. 154 for a related comment on 23a32.) He will try 'the good person' in paragraph [2.5.13]; in paragraph [2.5.11] he leaves it ambiguous.

Now Aristotle's argument is about the essence of the good (thing /person/...), which he says contains the good. In Ibn Sīnā's framework objects don't have essences; ideas do. So we have to suppose that we are thinking about the good (thing/person/...) through some idea that identifies it, and [GOOD] is in the essence of this idea. But how is this to work?

Suppose for example that we are thinking about Nelson Mandela; then Aristotle's argument assumes that [GOOD] is constitutive for [NELSON MANDELA]. But how could it be? Isn't it clear that we could imagine even Nelson Mandela turning evil, polluting the environment and depriving old ladies of their pension funds? Ibn Sīnā accepts the raf ${ }^{c}$ test in this direction.

The same problem applies if we take 'it' in Aristotle's 'the good' to stand for any one particular good entity - unless perhaps we believe in Platonic ideas, which Ibn Sīnā didn't. I think this leaves the argument of [2.5.13] as unrescuable, and that seems to be Ibn Sīnā's conclusion too. But we can more or less rescue paragraph [2.5.11] by reading 'the good' generically, like 'the human' or 'the horse'. Then to say that the good is good is in effect to assert the meaning [EVERYTHING GOOD IS GOOD]. I have translated it on that assumption. 
128.2 With several manuscripts, read hīna kāna $i^{c}$ tiqād in place of muqābilun lil-ictiquad.

[2.5.12] This comments on Perì Hermēneías 23b21f.

128.5 'more strongly true': Ibn Sīnā is quietly reprimanding Aristotle for a careless statement. Aristotle had said:

The more true belief about anything is the one about what

it is in itself. (23b17, trans. Ackrill [1] p. 66.)

For example the belief that gold is a metal is more true than the belief that gold has high market value. This is incorrect, says Ibn Sīnā; both beliefs are simply true, but Aristotle could have made his point by saying that the belief about the essence is more permanent than that about an accidental property. 'Permanent' should probably be understood as in $\S 3.3$ : a belief is more permanent if it is more resistant to changing truth value when one changes it by changing the 'reading' of the time or circumstance that it applies to.

[2.5.13] This is a second attempt at Perì Hermēneías 23b15-21, which Ibn Sīnā has already tackled in [2.5.11].

128.11f 'mental processor' $(b \bar{a} l)$ : Ibn Sīnā has a number of words for different aspects of mind. One of the most specific is $b \bar{a} l$. It's the part or aspect of the mind where rational processing takes place. His normal idioms for it are yakțir bil-bāl ('it comes into the mind') and 'uktir bil-bāl ('it is brought to the notice of the mind'). This notion of $b \bar{a} l$ need not be an intrusion of psychology into logic. It's better seen as part of a high-level description of the algorithms needed for reasoning.

The extent to which these algorithms probe the structure of the relevant sentences gives an upper bound on the proving power of aristotelian logic. For example, with a few minor reservations, the algorithms never penetrate an NP-VP sentence further than separating the NP from the VP. (This is one formulation of Toplevel Processing, §3.1). Line 128.12 is a typical illustration of this, with the NP and VP (or strictly their meanings) called respectively 'subject' and 'predicate'.

128.11 'essential truth': I.e. truth about the essence. As in the notes on [2.5.11], Ibn Sinnā must mean here the essence of the idea of this 
just individual, for example [NELSON MANDELA]. Here he touches on the hoary problem of the meanings of proper names. At Madkal [11] 31.9 he suggests that the essence of the idea of an individual contains 'whatever [the individual] is individuated by', but I don't know if he succeeds in taking this semantic question any further.

129.3 'forced way' (takalluf): One of Ibn Sīnā's commonest criticisms of other commentators is that their explanations are forced. In this case there is an implied criticism of Aristotle himself - that his argument can only be explained in a forced way. Presumably the forced point is the assumption that the essence of (the idea of) any individual person can contain [GOOD]; see the notes on [2.5.11].

[2.5.14] This comments on Perì Hermēneías 23b27-32.

129.10 'not': following the reading $l \bar{a}$ rather than lahā.

[2.5.15] This looks like a comment on something in the literature, but we don't know what.

[2.5.16] See $\S 5.3$ for the source.

129.15 'his level of deficiency' ( ${ }^{c}$ ahdah): The noun ${ }^{c}$ ahd has several meanings, none of them clearly appropriate here; so if the text is sound, it's likely that some idiom hasn't come down to us. But since what follows is specific to an individual commentator, probably Ibn Sīnā's phrase is meant to insult this commentator rather than to describe some other people. An ${ }^{c} u h d a$ is a claim you have against a person who has sold you substandard goods, and hence it comes to be used metaphorically for an attribute in which one is below standard. Commercial metaphors appear also at Easterners [17] 24.18 (' ${ }^{c} u h d a$ again) and 'Išārāt [18] 67.8 (hawāla).

129.15 'this argument': Paragraph [2.5.14] lines 129.8-9, 'every affirmative proposition has a negation that conflicts with it'. The commentator 'supports' it in the sense of using it as a premise for a further argument.

130.4 'and the conclusion is affirmative': The clause is missing from the text, but the argument needs it. Lo and behold, there it is in the text at 130.6 (marked [[...]] in the translation) where it 
makes no sense at all. Presumably Ibn Sīnā himself, editing the passage, saw that the clause was needed and added it in the margin. The copyist wasn't concentrating and managed to incorporate it at the wrong place. There are many places in Ibn Sīnā where one suspects that something like this has happened, but this is a particularly clear example (thanks to the constraints of formal argument).

130.4 'singular': Literally 'specialised'. Ibn Sīnā's point may be that the subject is 'the property of the thing, viz. that in all cases ...', which is singular, but the argument is made no less valid if we replace this by 'every property of the thing such that in all cases ...'. So without loss we can consider the conclusion as universally quantified.

130.10 'the major premise is false': The major premise is the second premise in (45). Ibn Sīnā reads it as implicitly universally quantified; so it says that the only thing true in all cases is that a belief has a contradictory opposite belief. But the implied subjects true beliefs - have lots of other properties that hold in all cases, for example being true beliefs.

130.16 'Anything found in all cases': According to Ibn Sīnā's account at 130.1, the commentator had said something of the form 'An $A$ is a $B^{\prime}$. His argument clearly calls for this to imply 'Every $B$ is an $A^{\prime}$. But 'An $A$ is a $B^{\prime}$ can quite naturally be read as

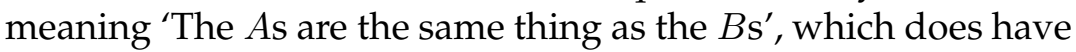
the required implication. Maybe Ibn Sīna counts this reading as one of those things that are merely 'suggested' by the commentator's sentence, as in $\S 3.3$ above. But professionalism should have warned him to start with the reading most likely to have been intended.

That much is from the form of the argument. When we turn to the content, the commentator seems to be claiming that if an idea $I$ has an attachment $J$ that holds 'in all cases', then $J$ is constitutive for $I$. If 'all cases' includes imagined cases as well as real-world ones, then the claim is simply Porphyry's claim that non-constitutives can be separated off by raf $f^{c}$ in the imagination. As we saw in §3.2, Ibn Sīnā himself rejected this claim — so it's no surprise that he labels it as 'obviously false'.

[2.5.17] This comments on Perì Hermēneías 23b33-24a3. 
130.18 'relevant': The restriction to these forms is from Aristotle. Ibn Sīnā makes no attempt to justify it. Maybe he has in mind some canonicality argument as in $\S 4.3$.

[2.5.18] This comments on Perì Hermēneías 24b1-9.

131.7 'universally quantified': These are sentences of either of the forms 'Every $A$ is a $B^{\prime},{ }^{\prime}$ No $A$ is a $B$ '.

131.10 'is good' (second occurrence): This is reading huwa kair with two manuscripts. The majority reading laisa bi-kair 'is not good' makes logical nonsense.

131.11 'account': Singular sentences are of either of the two forms ' $A$ is a $B^{\prime}, ' A$ is not a $B^{\prime}$, where $A$ names an individual. The account applying to both these and universally quantified sentences is that we get the contrary by swapping ' $B$ ' and 'not a $B$ ' — where 'No $A$ is a $B$ ' is counted as 'Every $A$ is not a $B$ '.

131.12 'unquantified': For Ibn Sīnā these are sentences of the forms 'The $A$ is a $B^{\prime}$, 'The $A$ is not a $B^{\prime}$.

131.12 'Contraries': This last sentence picks up the final sentence of Aristotle's text. The common core of the two sentences is (in

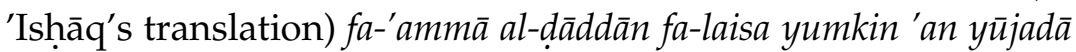
$m a^{c} a n$, and (in Ibn Sīnā) wal-'addēd fa-laisa yajūz 'an tașduq macan. Both mean 'Contraries can't be true together', but Ibn Sīnā replaces most of the significant words by other words that have the same meaning in context. Thus he replaces the dual daddān by a

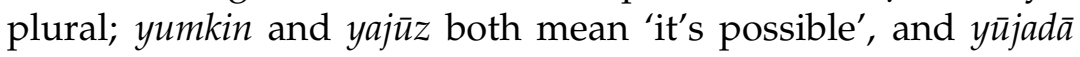
and tașduq both mean 'are true'. Differences like these could be evidence that Ibn Sīnā is using a different translation from 'Ishāq's. But they are par for the course in Ibn Sīnā, and a more likely explanation is that he prefers to assert his independence by saying everything in his own words.

\section{References}

[1] J. L. Ackrill, Aristotle's Categories and De Interpretatione, Translated with Notes and Glossary, Clarendon Press, Oxford 1963.

[2] Al-Fārābī, Commentary on Aristotle's De Interpretatione, ed. W. Kutsch and S. Marrow, Dar el-Machreq, Beirut 1986. 
[3] Ammonius, In Aristotelis De Interpretatione Commentarius, ed. Adolfus Busse, Reimer, Berlin 1897.

[4] Jonathan Barnes, Porphyry: Introduction, Clarendon Press, Oxford 2003.

[5] George Boole, The Nature of Logic (1848), in George Boole: Selected Manuscripts on Logic and its Philosophy, ed. I. Grattan-Guinness and G. Bornet, Birkhäuser, Basel 1997, pp. 1-12.

[6] William Charlton, "Philoponus" on Aristotle's On the Soul 3.9-13 with Stephanus on Aristotle's On Interpretation, Cornell University Press, Ithaca New York 2000.

[7] Gottlob Frege, 'Grundlagen der Geometrie', Jahresbericht der Deutschen Mathematikervereinigung 12 (1903) 319-324, 368-375; 15 (1906) 293-309, 377-403, 423-430.

[8] Dimitri Gutas, Avicenna and the Aristotelian Tradition: Introduction to Reading Avicenna's Philosophical Works, Brill, Leiden 1988.

[9] Wilfrid Hodges, 'Natural language logic versus aristotelian logic', Festschrift volume for Johan van Benthem, ed. Hans von Ditmarsch and Larry Moss.

[10] Ibn al-Tayyib, Commentary on Porphyry's Eisagoge, ed. Kwame Gyekye, Dar el-Machreq, Beirut 1975.

[11] Ibn Sīnā, Al-Madkal, ed. Ibrahim Madkour et al., Našr Wizāra al$\mathrm{Ma}^{c} \bar{a}$ rif al- ${ }^{c}$ Umūmiyya, Cairo 1951.

[12] Ibn Sīnā, Al-Maqūlāt, ed. Ibrahim Madkour et al., Našr Wizāra alTaqāfa wal-'Iršād al-Qūmī 1959.

[13] Ibn Sīnā, $A l^{c}{ }^{c} I b a \bar{r} r a$, ed. Ibrahim Madkour et al., Dār al-Kātib al- ${ }^{c}$ Arabī lil-Ṭabā $\bar{a}^{c}$ wal-Našr, Cairo 1970.

[14] Ibn Sīnā, Al-Qiyās, ed. Ibrahim Madkour et al., Našr Wizāra al-Taqāāa wal-'Iršād al-Qūmī 1964.

[15] Ibn Sīnā, Al-Burhān, ed. ${ }^{c}$ Abdurraḥmān Badawī, Dār al-Nahḍa al${ }^{c}$ Arabīyya, Cairo 1966.

[16] Ibn Sīnā, Al-Jadal, ed. A. Ahwānī, Našr Wizāra al-Ṭaqāfa wal-'Iršād al-Qūmī 1965. 
[17] Ibn Sīnā, Manțiq al-Mašriqiyyīn, Al-Maktaba al-Salafiyya, Cairo 1910.

[18] Ibn Sīnā, Al-'Išārāt wal-Tanbiyyāt, ed. Mojtaba Zāre ${ }^{c} \overline{1}$, Būstān-e Ketab-e Qom, Qum, Iran 2000. (The logical part is translated: Shams C. Inati, Ibn Sinnā, Remarks and Admonitions, Part One: Logic, Pontifical Institute of Mediaeval Studies, Toronto 1984.)

[19] Farīd Jabre (ed.), Al-Nașs al-Kāmil li-Manțiq 'Arisțū Vol. 1, Dār al-Fikr al-Libnān̄̄, Beirut 1999.

[20] Ray Jackendoff, Semantic Structures, MIT Press, Cambridge Mass. 1990.

[21] Joep Lameer, Review of 'Glosses and Commentaries etc., ed. Charles Burnett', Journal of the American Oriental Society 116 (1996) 90-98.

[22] Paolo Mancosu, Philosophy of Mathematics and Mathematical Practice in the Seventeenth Century, Oxford University Press, New York 1996.

[23] Graham Oddie, 'Truthlikeness', Stanford Internet Encyclopedia of Philosophy, plato.stanford.edu.

[24] Proclus, A Commentary on the First Book of Euclid's Elements, ed. Glenn R. Morrow, Princeton University Press, Princeton NJ 1970.

[25] Paul Thom, The Syllogism, Philosophia Verlag, Munich 1981.

[26] Paul Thom, Medieval Modal Systems, Ashgate, Gateshead 2003.

[27] C. W. A. Whitaker, Aristotle's De Interpretatione: Contradiction and Dialectic, Clarendon Press, Oxford 1996.

[28] Yahyāi ibn ${ }^{c}$ Adī, Maqālāt Yahyā ibn ${ }^{c}$ Ad̄̄ al-Falsafiyya, ed. Sahban Khalifat, Amman 1988.

[29] F. W. Zimmermann, Al-Farabi's Commentary and Short Treatise on Aristotle's De Interpretatione, British Academy and Oxford University Press, Oxford 1981. 